\title{
STUDIES ON CRUSATCEAN PARASITES OF FRESHWATER FISHES OF MYSORE
}

\author{
Part I. Morphology of a New Copepod Parasite Lernaea hesaragattensis \\ sp. nov. on Lebistes reticulatus (Peters) \\ H. R. Srinivasachar* and A. Sundarabai** \\ Received March 27, 1974 \\ (Communicated by Prof. B. R. Seshachar, F.A.sc.)
}

\begin{abstract}
The morphology of a new copepod parasite Lernaea hesaragattensis has been described. The infection appears to be maximum during July and minimum during January. The parasite is found generally attached at the base of the fins of the host fish, Lebistes reticulatus. The adult female parasite measures 6-9 $\mathrm{mm}$, and possesses a pair of ovisacs measuring 2-3.5 mm, with 120-140 eggs in each sac. The abdomen is distinctly 3-jointed and extends posteriorly at an angle from the thorax. The pregenital prominence which marks the posterior end of the thorax is in the form of a large undivided lobe.
\end{abstract}

\section{INTRODUCTION}

YamaguTl (1963) has listed 45 species of Lernaea parasitic on fishes from various parts of the world. But so far only two species, L. chackoensis and $L$. bengalensis have been reported from India (Gnanamuthu, 1951 $a$, $195 \mathrm{I} b$, 1956). In an earlier paper (Srinivasachar and Sundarabai, 1971) a preliminary account of the new species $L$. hesaragattensis parasitic on the Cyprinodont fish, Lebistes reticulatus, has been given. This copepod parasite differs both in morphology and life-history from the species described so far, as also in host specificity. Although the fish fauna of Mysore is fairly well known, relatively little is known about the parasites of the fishes. This paper attempts to fill a lacuna in our knowledge of copepod parasites. The systematics and morphology of the new species $L$. hesaragattensis are described in this paper and the life-history will be reported in the next part.

* Department of Zoology, Bangalore Universily, Central College, Bangalore.

** Dspartment of Zoology, University of Agricultural Scionces, Hebbal, Bangalore560024. 


\section{Materials AND MethodS}

The parasite was first collected in September 1969 from a tank in Hesaraghatta (15 miles from Bangalore) during the course of a routine investigation of the fish fauna of the area. Subsequently, regular collections were made from an experimental tank in the same locality over a year in order to understand the seasonal variations and also the incidence of infection. The number of fishes collected each month and the number of infected fishes among them, with the details of attachment, are given in Table I.

Due to the relatively small size of the host, the parasite causes considerable damage to the host fish. In addition to feeding on the host blood occasionally, the parasite causes much damage to the host consequent on its large anchor displacing the internal organs of the latter. Severe haemorrhages and necrosis also occur.

In all, 685 parasites were collected from September 1, 1969 till the end of August 1970. The parasites were collected from Lebistes reticulatus and though the tank had other fishes like Cyprinus carpio, Labeo sp., Barbus sp., none of them showed the parasites. In most cases the parasites were covered by colonies of peritrichous ciliates such as Vorticella, Carchesium and Epistylis, rotifers and also algae, oscillatoria filaments and diatoms. With thick encrustations of peritrichous ciliates and algae, the parasites died soon after they were brought to the laboratory. If one removed the dead parasites from the body of the sluggish fish, they became active and led normal lives. The death of the heavily encrusted parasites could be due to the obstruction to the normal respiration of the parasites.

To study the parasites, they were separated from the host lish, lixed in $90 \%$ alcohol or Bouin's fluid and transferred to $70 \%$ alcohol. Some were fixed in $10 \%$ formalin and later transferred to $4 \%$ formalin. They were stained in borax carmine after an earlier treatment for 5 minutes with $3 \%$ $\mathrm{KOH}$ and $10 \%$ acetic acid. Some of the parasites were mounted directly by using Berlise fluid to study the appendages.

\section{OBSERVATIONS}

The parasite, Lernaea hesaragattensis sp. nov. was generally observed to be attached to the fish at the base of the fins. As seen in Table I, the base of the pectoral fin was the most favoured spot for attachment. However, parasites were also observed at the base of dorsal, anal and caudal fins. They were embedded in the muscular tissue. All the adults collected 


\section{TABLE I}

\begin{tabular}{|c|c|c|c|c|c|c|c|c|}
\hline \multirow[b]{2}{*}{ No. } & \multirow[b]{2}{*}{ Month } & \multirow[b]{2}{*}{$\begin{array}{l}\text { Total } \\
\text { No. of } \\
\text { fishes } \\
\text { collected }\end{array}$} & \multirow[b]{2}{*}{$\begin{array}{l}\text { No. of } \\
\text { fishes } \\
\text { infected }\end{array}$} & \multirow[b]{2}{*}{$\begin{array}{l}\text { At the } \\
\text { base of } \\
\text { pectoral } \\
\text { fin }\end{array}$} & \multicolumn{3}{|c|}{ Parasites attached } & \multirow[b]{2}{*}{$\begin{array}{l}\text { Number of } \\
\text { fishes } \\
\text { having more } \\
\text { than } 1 \text { parasite }\end{array}$} \\
\hline & & & & & $\begin{array}{l}\text { At the } \\
\text { base of } \\
\text { dorsal } \\
\text { fin }\end{array}$ & $\begin{array}{l}\text { At the } \\
\text { base of } \\
\text { anal } \\
\text { fin }\end{array}$ & $\begin{array}{l}\text { In other } \\
\text { regions } \\
\text { of the } \\
\text { body }\end{array}$ & \\
\hline 1 & 2 & 3 & 4 & 5 & 6 & 7 & 8 & 9 \\
\hline 1. & Sept. 1969 & 394 & 16 & 12 & 1 & 1 & 2 & $\cdots$ \\
\hline 2. & Oct. 1969 & 415 & 69 & 39 & 3 & 15 & 12 & $2(2)$ \\
\hline 3. & Nov. 1969 & 286 & 26 & 19 & 2 & 1 & 4 & $2(2)$ \\
\hline 4. & Dec. 1969 & 345 & 15 & 8 & 1 & 2 & 3 & $\cdots$ \\
\hline 5. & Jan. 1970 & 120 & 2 & 1 & . & . & 1 & . \\
\hline 6. & Feb. 1970 & 374 & 7 & 4 & 1 & $\ldots$ & 1 & $\cdots$ \\
\hline 7. & March 1970 & 65 & 10 & 5 & 2 & 2 & 1 & $\cdots$ \\
\hline 8. & April 1970 & 695 & 203 & 126 & 4 & 10 & 3 & $3(2), 1(3)$ \\
\hline 9. & May 1970 & 163 & 26 & 18 & 4 & 3 & 1 & $4(2), 1(3)$ \\
\hline 10. & June 1970 & 355 & 49 & 28 & 6 & 8 & 7 & $5(2)$ \\
\hline 11. & July 1970 & 768 & 224 & 159 & 23 & 18 & 24 & $7(2)$ \\
\hline 12. & Aug. 1970 & 443 & 54 & 29 & 8 & 7 & 10 & $2(2)$ \\
\hline
\end{tabular}

Note.-The number shown in parenthesis in column 9 represents the number of parasites attached to a single host.

were females. Infection appears to be maximum during July (Fig. 1) and minimum during January.

Adult female.-The total length of adult female (Fig. 2) varied from $6 \mathrm{~mm}$ to $9 \mathrm{~mm}$, excluding the egg sacs (OS) and anal laminae (AL). The 
parasite is transparent and slightly brownish in colour. The alimentary canal (OES, INT), which can be observed through the chitinous exoskeleton, showed a number of dark granules. An adult female of $8 \mathrm{~mm}$ showed the following measurements:

\begin{tabular}{llll}
\multicolumn{2}{c}{ Head to I segment } &.. & $0.9 \mathrm{~mm}$ \\
I Appendage to II appendage &.. & $0.8 \mathrm{~mm}$ \\
II Appendage to III appendage &.. & $1.4 \mathrm{~mm}$ \\
III Appendage to IV appendage &.. & $2.0 \mathrm{~mm}$ \\
IV Appendage to V appendage &.. & $1.6 \mathrm{~mm}$ \\
$\quad$ Abdomen &.. & $1.3 \mathrm{~mm}$ \\
$\quad$ Length of egg sacs &.. & $2.8 \mathrm{~mm}$
\end{tabular}

The head (Figs. 2, 4, H) is circular and projects from the body in the form of a protuberance. The region below the head is extended in the form of highly branching asymmetrical arms (Fig. 2, DLA, VLA) arranged at right angles to each other. All the adult female parasites collected showed these highly branching asymmetrical arms; the branching did not conform to any particular pattern, but exhibited great variations. The first thoracic

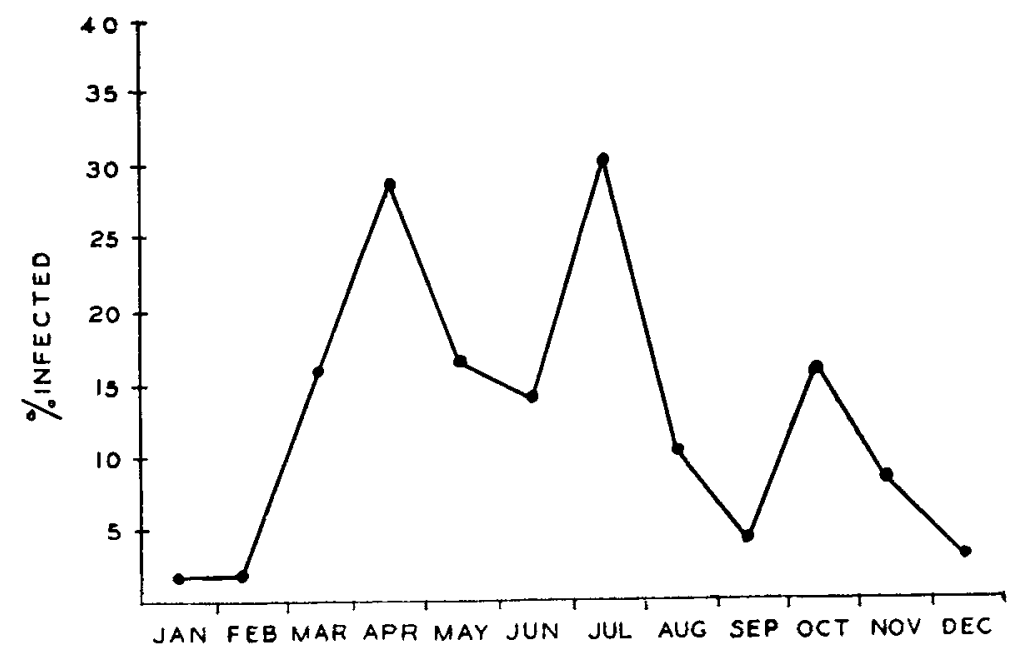

FIG. 1. Incidence of infection of the copepod parasite, Lernaea hesaragattensis during different months.

segment is fused with the head and the first pair of appendages (Figs. 2, $9, I L)$ marks the limit of the posterior region of the segment. There is a 

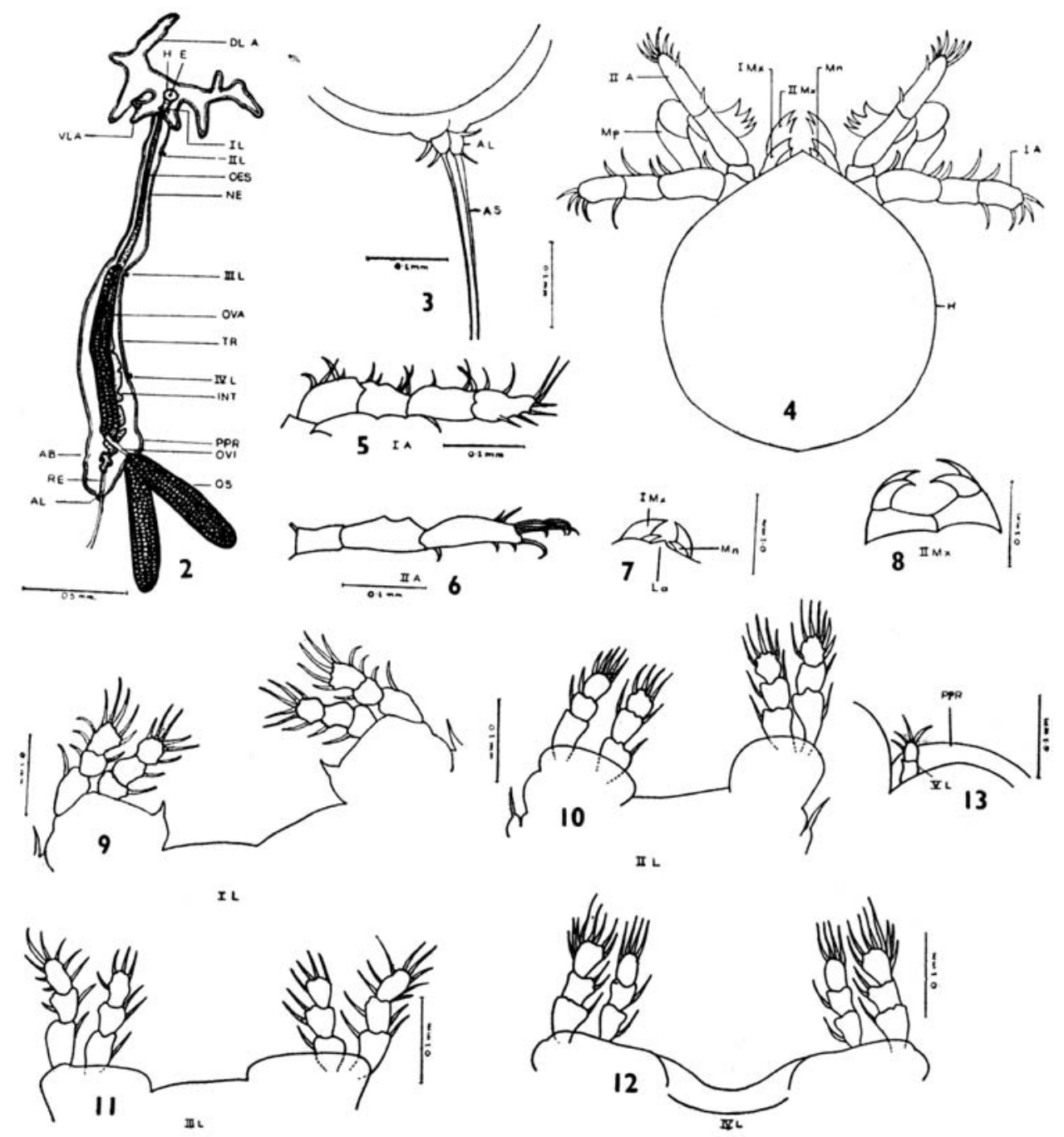

Figs. 2-13. Adult female parasite, Lernaea hesaragattensis and different parts of the body. (I A, II A, first and second antenna ; AB, abdomen; AL, anal lamina; AS, anal seta; DL A, dorsal lobe arm; E, eye; H, head; INT, intestine; I L, II L, III L, IV L, I pair of legs-IV pair of legs; V L, fifth leg; $M n$, mandible; $M p$, maxillipede; I $M x$, II $M x$, first and second maxilla; NE, neck; OES, oesophagus; OS, ovisac; OVA, ovary; OVI, oviduct; PPR, pregenital prominence; RE, rectum; TR, trunk,; VLA, ventral lobe arm. Fig. 2. Lateral view; Fig. 3. Posterior end. Fig. 4. Head with appendages. Fig. 5. First antenna. Fig. 6. Second antenna. Fig. 7. First maxillae and mandibles. Fig. 8. Second maxillae. Fig. 9. First pair of legs. Fig. 10. Second pair of legs. Fig. 11. Third pair of legs. Fig. 12, Fourth pair of legs. Fig. 13. Fifth leg. 
torsion of the body anteriorly, the torsion extending to the level of the second pair of appendages (Figs. 2, 10, II L). The neck (Fig. 2, NE) is narrower than the rest of the body, slightly swollen at the region of the attachment of the second pair of appendages and extends as far as the third pair of legs (Figs. 2, 11, III L). The region behind the third pair is the trunk (Fig. 2, TR) which is gradually enlarged, and shows the fourth (Figs. 2, 12, IV L) and fifth pair of legs (Fig. 13, V L). Behind the fifth pair of legs lies the pregenital prominence (PPR) which is in the form of a large undivided lobe and marks the posterior end of the trunk, it is held at an angle, is distinctly three-jointed (Fig. 2, AB) and ends in a pair of anal laminae (Figs. 2, 3, AL) on either side of the anus. Each lamina has one inner and one outer short spine and terminates in a long straight seta (Fig. 3, AS).

Appendages.-The head bears two pairs of antennae (Fig. 4, I A and II A) extending on either side of the eyes. The eyes (Fig. 2, E) are median and are subdermal in position. The first pair of antennae (Fig. 5, I A) is four-jointed and bears 24 spines in all while the terminal segment bears eight spines of which two are longer than the rest and are straight. The second antennae (Fig. 6, II A) is shorter, three-jointed and bears ten spines of which five are sharply curved and borne on the terminal joint. The mandibles (Figs. 4, 7, Mn) are short blade-like structures located on either side of the labrum (Fig. 7, La) and are without serrations. The first maxillae (Figs. 4, 7, I $M x$ ) are also blade-like structures but are larger than mandibles. The second maxillae (II $M x$ ) consist of a basal segment which bears distally two curved blades fused together at the proximal end. The maxillipedes (Fig. 4, Mp) are prominent and bear distally four toothlike projections.

There are five pairs of thoracic legs. The first pair (Fig. 9, I L) occurs at the base of the head protuberance. The second, third and fourth pair of legs (Figs. 10, 11, 12, II L, III L, IV L) are located on the neck and trunk and the spacing of the legs varies with the length of the parasite. All the four pairs of the thoracic legs are typically biramous, having the exopod and endopod each with 3 joints and a broad basal segment. The exopod and endopod of each thoracic leg bears spines and the number of spines varies from 6 to 12 , distributed on the different segments. The basal segments of first two pairs of thoracic legs bear spines. The fifth pair of legs (Fig. 13, V L) is vestigial and appears uniramous and is almost hidden by the bulge of the pre-genital prominence. Each leg has a small distal joint with four spines. 


\section{DISCUSSION}

Since Leigh-Sharpe (1925) described the first Asiatic species of Lernaea, L. elegans, from Anguilla japonica, several species, L. polymorpha, L. parasiluri, L. brachycera (Yu, 1938), L. rhodei (Hu, 1948), L. chackoensis, L. bengalensis (Gnanamuthu, 1951, 1956) have been reported from China, Japan and India. Wilson (1917) in a detailed description of the genus Lernaea has observed that the structure and branching of the arms cannot be taken as stable characters in determining the species. The anchor arms are simple without any branches in the young of $L$. hesaragattensis and become highly branching and asymmetrical in the aduit as in L. chackoensis (Gnanamuthu, 1951). Fryer (1961) has observed in L. inflata that anchor arms are unbranched ventrally and branched dorsally and further that the site of attachment exerts considerable effect on the shape and branching of the anchor in L. barnimiana, parasitic on Barbus altianalis radcliffi. This parasite is found mostly in the buccal cavity of the host fish. But $L$. hesaragattensis is normally found attached to the base of fins, and due to small size of the host fish, the parasite is deep rooted and establishes firmly with the help of highly branching anchor arms. In L. barnimiana (Fryer, 1961), the parasite can be easily separated from the host fish; in L. hesaragattensis, however; it cannot be pulled out without damaging the anchor arms. The branching of the arms is also extensive in the adult parasite, as in $L$. chackoensis (Guanamuthu, 1951).

The pregenital prominence in L. chackoensis (Gnanamuthu, 1951) and L. inflata (Fryer, 1961) is distinctly divided into two lobes, but in L. hesaragattensis, it is in the form of a single large lobe almost covering the fifth pair of thoracic legs. The abdomen is simple and tubular in L. inflata (Fryer, 1961); in L. chackoensis (Gnanamuthu, 1951) in older animals it does not exhibit the constrictions, though in the younger stages the segments are distinct. However, in $L$. hesaragattensis the abdomen shows distinctly three segments in both the younger and older forms.

L. hesaragattensis appears to be the only species parasitic on Lebistes reticulatus; other species of Lernaea are found on larger fishes (Yamaguti, 1963).

\section{REFERENCES}

Fryer, G., The parasitic copepods and branchiura of the fishes of Lake Victoria and the Vickoria

Nile. Proc. Zool. Soc. Lond. 13741 (1961). 
Gnanamuthu, C. P., Lernaea chackoensis $\mathfrak{n}$. sp., a copepod parasitic on two Madras fishes. Parasitology 41143 (1951 a).

Gnanamuthu, C. P., Notes on the life-history of a parasitic copepod, Lernaea chackoensis. Parasitology $41148(1951$ b).

Gnanamuthu, C. P., Lernaea bengalensis sp. nov. a copepod parasitic on Channa punctatus. Rec. Ind. Mus. 545 (1956).

Leigh-Sharpe, W. H., Lernaea elegans n. sp. a parasitic copepod of Anguilia japonica. Parasitology 17245 (1925).

Srinivasachar, H. R. and Sundarabai, A., A new copepod parasite Lernaea sp. nov. on a cyprino dont fish Lebistes reticulatus (Peters). Curr. Sci. 40453 (1971).

Wilson, C. B., North American copepods belonging to the Lernaeidae with a revision of the entire family. Proc. U.S. Nat. Mus. 53150 (1917).

Yu, S. C., Some parasitic copepods from the freshwater fishes of China. Bull. Fan. Mem. Inst. Biol. (Zool. Series) 8 (2) 105 (1938).

Yamaguti, S., Parasitic Copepods and Branchiure of Fishes. Interscience Publishers, New York (1963).

Hu-Ynung-Tsu, Studies on the parasitic copepods of China. Part III. Sinensia 1984 (1948). 